Article

\title{
New Challenges Regarding the Intervention of Musculoskeletal Risk in Truck Service Garages
}

\author{
Coral Oliver Hernández ${ }^{1, *(\mathbb{D})}$, Shimeng $\mathrm{Li}^{2}{ }^{\mathbb{D}}$, María José Aguado Benedi ${ }^{1}$ and Inmaculada Mateo Rodríguez ${ }^{3,4,5}$ \\ 1 Department of Social, Work and Differential Psychology, Faculty of Psychology, Complutense University of \\ Madrid, 28223 Madrid, Spain; mjaguado@ucm.es \\ 2 Interuniversity Doctoral Programme in Health Sciences, University of Seville, 41004 Seville, Spain; \\ shimengl@ucm.es \\ 3 Andalusian School of Public Health, 18080 Granada, Spain; inmaculada.mateo.easp@juntadeandalucia.es \\ 4 CIBER of Epidemiology and Public Health (CIBERESP), 28029 Madrid, Spain \\ 5 Department of Social and Organizational Psychology, Faculty of Psychology UNED, 28040 Madrid, Spain \\ * Correspondence: maoliver@ucm.es; Tel.: +34-607-230-987
}

check for

updates

Citation: Oliver Hernández, C.; Li, S.; Aguado Benedí, M.J.; Mateo Rodríguez, I. New Challenges Regarding the Intervention of Musculoskeletal Risk in Truck Service Garages. Sustainability 2022, 14, 181. https://doi.org/10.3390/su14010181 Academic Editors: Julio Blanco, Emilio Jimenez and Francisco Flor-Montalvo

Received: 15 November 2021 Accepted: 15 December 2021 Published: 24 December 2021 Publisher's Note: MDPI stays neutral with regard to jurisdictional claims in published maps and institutional affiliations.

Copyright: (c) 2021 by the authors. Licensee MDPI, Basel, Switzerland. This article is an open access article distributed under the terms and conditions of the Creative Commons Attribution (CC BY) license (https:// creativecommons.org/licenses/by/ $4.0 /)$.

\begin{abstract}
Background: The automotive industry is heavily affected by sick leaves caused by the handling of loads and using postures that produce musculoskeletal disorders. Research is needed to analyse their causes and find possible solutions to eliminate or mitigate these risks. Objective: Our objective was to analyse the level of musculoskeletal risk in the different work tasks performed by truck and bus mechanics. Our intention is also to analyse whether postural training and feedback can help reduce risk. Methods: The rapid entire body assessment (REBA) was used to assess the postures performed by 35 mechanics from eight branches throughout Spain. The participants were subsequently divided randomly into two groups (experimental group and control group). The experimental group (EG) was given training and feedback on their postures and the control group (CG) was not offered any type of intervention. A few months after the initial assessment, their postural load in the usual tasks was re-evaluated. Results: An overall average REBA Score: $10.49 \pm 1.33$. The main risk was found in the trunk and arms with sustained above-the-head postures. EG's second results are significantly improved compared to the first $\left(p=0.026^{*}\right)$. Conclusions: These jobs have a high-risk level of musculoskeletal disorders. The course of action presented with postural training and feedback has shown satisfactory results. Nevertheless, given the size of the sample, further research will be needed to delve deeper into this possibility as a future line of intervention.
\end{abstract}

Keywords: REBA method; automotive; postural feedback; musculoskeletal disorders; ergonomic training

\section{Introduction}

The analysis of the report on the main activities based on accident rates for 2019 [1] indicates that there were 60,929 work accidents with sick leave and 42 fatalities in the vehicle repair economic activity, with one of the main causes of these workday accidents with sick leave being injuries due to overexertion from the handling of loads and using postures that create musculoskeletal disorders (MSD). These sick leaves lead the list of accidents with a total of 139,618 in 2020. The types of injuries with the greatest number of cases, 189,279, were dislocations, sprains, and strains.

According to data released by the UK in 2020, about 480,000 workers are affected by MSD, and the prevalence rate of mechanics is significantly higher than that of all occupations. This disorder mainly affects the neck, upper limbs, and back [2]. The EU report is similar to this result [3]; there were 62,511 cases of back and spine affected in 2020, followed by upper limbs and including fingers (55,623 cases), hands (29,409 cases), and shoulders (23,015 cases). According to the National Institute for Occupational Safety and Health, "There is a causal relationship between musculoskeletal injuries and disorders and workplace exposure to forced exertion, uncomfortable postures, and vibrations" [4]. 
Various research studies carried out in different labour sectors stand out, and all agree to have found a close relationship between manual handling of loads, using incorrect postures, and musculoskeletal disorders. This is the case in studies by Lyons [5] and Szeto [6], related to drivers of heavy transport vehicles, along with Galinsky's research [7] on home health workers, as well as Fonseca's findings [8] that report the existence of "factors associated with musculoskeletal problems in nursing assistants and nursing techniques".

More closely linked to this research, Cebrián Angulo [9] pointed out that in the automotive service industry, workers handle car parts such as wheels, batteries, gearboxes, or bumpers. All may force workers to use postures and strengths that exceed physical limitations. Moreover, many studies confirmed that repetitive tasks, manual handling of heavy objects, and continuous awkward posture are risk factors for TME [10-12]. Therefore, imparting ergonomic knowledge and improving the working environment to workers can prevent them from adopting harmful postures at work, which is essential for improving the well-being of workers.

The company in which the study was carried out is a multinational one dedicated to the manufacture, repair, and maintenance of heavy trucks, buses, and diesel engines. According to their data on accident rates, most workplace accidents and the damage suffered are caused by overexertion and injuries to the musculoskeletal system, especially to upper extremities, and are mostly suffered by those who work as mechanics. This position has the highest incidence of accidents, with $82 \%$ of the total. Of these, $43 \%$ occurred due to physical overexertion on the musculoskeletal system, and the part of the body recording the greatest number of injuries is the back, which includes the spine and dorsolumbar vertebrae.

The types of injuries that have resulted in workers taking sick leave following an accident in the workplace have been sprains and strains, which have the highest incidence in the garage, with a total of 51 cases representing $36.69 \%$, followed in second place by superficial injuries from foreign bodies with $22.30 \%$ of cases, and third, dislocations, sprains, and strains with $12.23 \%$.

These injuries usually occur in parts of the body where the need for physical exertion can be moderate or high. In the service garages, there have been 19 cases of workers who have taken sick leave due to some sort of pain in the back, spine, and dorsal vertebrae, representing $13.67 \%$. Regarding lower leg extremities, including the knee, these account for $10.07 \%$ of cases. Continuing with the upper extremities, finger injuries have the highest frequency of cases with $11.51 \%$, hand and arm including the elbow joint with $7.19 \%$, respectively, followed by ailments in the shoulder and humerus joints with $5.76 \%$ and the wrist with lower incidence, with six cases reported throughout the period.

Likewise, we can identify that the ages of workers with the highest percentage of accidents are those between 31 and 40 years of age, with almost $50 \%$ of the cases, followed by the age range of over 41 and under 50 , with $22.30 \%$. These data show that our study population is relatively young workers who, due to their age, have optimal muscle strength and physical conditions, and that the injuries they suffer from, some of them irreversible, might mainly be due to overexertion carried out in their work activity and not to age-related degeneration.

The objective of this study is to assess and analyse the musculoskeletal risk levels of male truck and bus mechanics for different tasks, and to find the industrial vehicle repair and maintenance task with greater postural load. It also aims to analyse whether musculoskeletal risks can be reduced, through training in ergonomics and good practices, and feedback on their posture during the task.

\section{Materials and Methods}

\subsection{Sample}

The study was carried out from April 2020 to June 2021. First, a cross-sectional observational design was used to assess musculoskeletal risk by establishing a series of task-related postures in their work environment. Next, an experimental design was used 
to assess changes in risk among the workers who were offered training and feedback (experimental group) as opposed to those who make up the control group.

The research was carried out in a multinational company with more than 49,000 people worldwide. In our country, the company has 428 people on staff, of which 155 are mechanics. All mechanics working on evaluation and training days were offered the opportunity to participate. In the end, a sample of 35 mechanics was obtained, representing $21 \%$ of the total number of mechanics. Of those who agreed to participate, 17 workers who volunteered to participate in the study were randomly assigned to an experimental group (EG), and 18 workers to a control group (CG).

It should be noted that, prior to the research, the company carried out a risk assessment on the tasks performed by the mechanics. It was concluded that there is a moderate risk of physical strain from manual handling of loads due to the bulkiness of the parts in industrial vehicles and the forced postures used to do the repairs. For work with hydraulic column lifts, the risk of physical strain has been evaluated as moderate/high. This is due to having to maintain forced positions while looking up and having to keep hands and arms above the shoulders to do repair and maintenance tasks, in many cases holding heavy loads in this position. Tasks are performed in the following positions: (1) neck with more than $20^{\circ}$ extension from the axis of the head and trunk, with lateral twists (head looking upwards), (2) arms bent and held more than $90^{\circ}$ above the shoulder, and (3) repeated twisting of the trunk.

This position, with arms raised above the shoulders, has been identified as the most damaging. This is due to the effort it entails and the consequences it has on the mechanics' health, as it is the most frequent cause of sick leave in this job. Therefore, the tasks performed in pits and/or on hydraulic column lifts are the ones that have been selected for the study (see Figure 1), and 35 mechanics are included from throughout Spain.

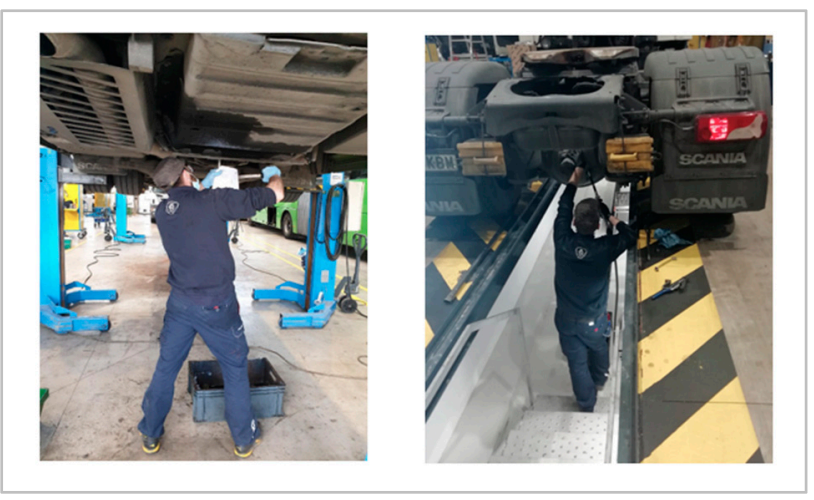

Figure 1. Positions of tasks in pit/with lift.

\subsection{Materials}

For the posture analysis, the REBA (rapid entire body assessment) method has been used, developed by the studies carried out since 1993 by Lynn McAtamney and Sue Hignett [13]. The REBA method has proven to have high intra-rater reliability for REBA raw scores and moderate inter-rater reliability (IRR) for a categorical scoring of REBA [14], and it has been used in many studies to analyze the musculoskeletal risk of postures adopted by auto industry workers during tasks [15-17]. The score that can be obtained is from 1 to 15 globally, but, in addition, the method allows the body to be divided into two parts: GROUP A (Trunk, Neck and Legs) and GROUP B (Arm, Forearm and Wrist). Each part is assigned a score according to the position, the higher the score the higher the risk. A sociodemographic questionnaire was used that can be consulted in Appendix A.

Other materials included: recording camera and tripod; paper; ballpoint. After the assessment, a training course and postural feedback were given. The training materials were meeting room, presentation equipment and presentation slides. 


\subsection{Study Method and Process}

The investigation was carried out in 6 phases and took a total of 14 months. Below is a description of the work carried out in each phase.

\subsubsection{Phase 1: Provide Informed Consent and a Research Fact Sheet}

First, workers are informed through an informed consent form that the purpose of the study is an analysis of the "Manual handling of loads and forced postures by mechanics working in service garages on repair and maintenance of industrial vehicles", and that all the information collected will be treated in a confidential manner and analysed overall. Under no circumstances will their individual results or any information that may identify them be published.

It is also explained that participation in this study is strictly voluntary, and they can leave at any time without having to give explanations or suffering any penalty.

They are given informed consent to record in writing the receipt of this information and to give their consent to participate in the study.

\subsubsection{Phase 2: Provide Questionnaire}

The sociodemographic questionnaire is given to the workers.

\subsubsection{Phase 3: Selection of the Most Unfavourable Posture and First REBA Assessment}

To select the postures, observation will be the basis to obtain data. The different postures used and movements performed by workers on a normal work day have been analysed.

Following the analysis and in line with results from the risk assessment, it was decided to delve deeper into research on the posture with arms raised above the shoulder used in tasks to repair the vehicles on hydraulic lifts and/or inside the pit.

The tasks they perform can be divided into the following:

- Vehicle maintenance, including oil change, filter changes (oil, air, diesel, pollen, etc.), and greasing steering knuckles.

- Gearbox repairs, including disassembling the transmission, shimming the engine, and removing screws from the casing. The clutch collar is disengaged, the gearbox is shimmed on the hydraulic table, and the gearbox is lowered to be repaired.

- Replacing the clutch. It is necessary to strip the transmission, shim the engine, remove screws from the housing, disengage the clutch collar, the gearbox is shimmed on the hydraulic table and is then lowered down. The screws holding the clutch cover are dismantled alternately (crossed) to remove pressure from the cover. The clutch is lowered out of the vehicle and cleaning is carried out to be able to insert the new part. And for assembly, the process is carried out in reverse.

- Assembly/disassembly of transmission. This is one of the most frequent tasks, as this is a part that links many of the vehicle's components and requires uncoupling (assembly/disassembly) and handling of the part to be able to do further repairs. The part weighs $60 \mathrm{~kg}$ and is difficult to grip.

- Changing the crankcase, draining the engine oil and removing the screws. In some cases 36 units of screws, clean the engine block, clean the sump gasket, and then assemble the new crankcase with the gasket.

To perform these tasks, the workers have different work tools and equipment at their disposal to facilitate carrying out the jobs, such as overhead crane, hoists, metal carts to support oil filters and spare parts, straps and/or slings to fasten parts, hydraulic lifts to position the vehicle at the most suitable height, work pits, and lifting tables to assist in supporting and transporting heavier parts during a repair.

An on-site analysis has been carried out in eight branches of the company, filming workers with a video camera as they carry out each task in order to later carry out an interjudge cross-validation. 


\subsubsection{Phase 4: Training/Feedback}

Once the data were collected, a random allocation was made between an experimental group (EG) and a control group (CG). The EG was provided with information and training, in various sessions, on the importance of good postural hygiene at their job and recommendations for stretching before and after the work day. The sessions also included postural feedback on how they perform their job, performed through pictures/videos of their own forced postures. This was intended to raise awareness on the risks they are exposed to, accompanied by a change in attitude to have an impact on improving their postures and how they organise their work. All of these variables are very relevant to the reduction of musculoskeletal risk in these types of jobs.

\subsubsection{Phase 5: Assessment Following Information, Training, and Feedback}

Some days later, the $17 \mathrm{EG}$ and $18 \mathrm{CG}$ workers were re-evaluated using the REBA method to analyse whether there was any change between the groups.

\subsubsection{Phase 6: Analysis of Results}

The SPSS 25.0 statistical software package (SPSS Inc., Chicago, IL, USA) was used to analyse the results. Independent sample $t$-test was used to compare the sociodemographic characteristics of EG and CG. The Kolmogorov-Smirnov test for normality was used to verify distribution of the data. Given that the distribution is not normal and the sample size is small, it was decided to do the analysis with nonparametric statistics. The Kruskal-Wallis test and Mann-Whitney $\mathrm{U}$ test were used for analysis of differences in $\mathrm{K}$ independent groups and two independent groups, respectively. For all tests, when the $p$-value is less than $<0.05$, it is considered statistically significant.

\subsection{Ethical Approval}

The research was authorized by SCANIA company and Complutense University of Madrid and approval was obtained prior to the study. In all cases, the mechanics who voluntarily participated in the research read and signed the informed consent form before the start of the study. This document clearly stated that participation is completely voluntary, and they can leave at any time without explanation or any punishment. And the researchers promise not to publish their personal data or any information that can identify them under any circumstances. The written informed consent form of the participants involved in the picture in this article can be seen in Appendix B.

\section{Results}

\subsection{The Sociodemographic Characteristics}

The sociodemographic characteristics of EG and CG participants were shown in Table 1, there were no significant differences in age, height, weight, BMI, and work experience between participants in the EG and CG groups. A total of 35 mechanics from eight different workplaces participated in the study. The workplace with the largest representation in the sample was Madrid with $51.43 \%$, of which $57.14 \%$ are experienced technicians, $28.57 \%$ skilled workers, and $14.29 \%$ semi-skilled workers. All were men, and the average age was $35.31 \pm 10.223$ years, the average work experience was $16.1 \pm 10.3$ years. The average height of the participants was $175.17 \pm 4.681 \mathrm{~cm}$. A relevant fact was that the average Body Mass Index (BMI) of the mechanics in the sample was 26.3 \pm 3.249 ; according to the classification [18] the average weight of the mechanics in the sample was higher than normal. 
Table 1. The sociodemographic characteristics of participants.

\begin{tabular}{cccccc}
\hline & GRUPO & N & Mean & SD $^{*}$ & $p$-Value $^{\dagger}$ \\
\hline \multirow{2}{*}{ Age } & Control & 18 & 33.44 & 7.72 & 0.27 \\
& Experimental & 17 & 37.29 & 12.27 & \\
Height & Control & 18 & 174.39 & 4.02 & 0.32 \\
& Experimental & 17 & 176.00 & 5.29 & \multirow{2}{*}{0.43} \\
Weight & Control & 18 & 80.50 & 10.78 & \\
& Experimental & 17 & 77.88 & 8.59 & \multirow{2}{*}{0.18} \\
\multirow{2}{*}{ BMI } & Control & 18 & 26.51 & 3.78 & \multirow{2}{*}{0.20} \\
& Experimental & 17 & 25.10 & 2.09 & \\
\hline
\end{tabular}

Note. ${ }^{*} \mathrm{SD}$, standard deviation. ${ }^{\dagger}$ Independent Sample $t$-test.

\subsection{Musculoskeletal Risk and Factors Associated}

After the assessments were carried out on the mechanics, a total of 43 movements were identified, divided into 5 types of tasks: assembly/disassembly of the transmission; replacing the crankcase; gearbox repair; vehicle maintenance (oil and filter changes); other less frequent tasks (replacing the clutch, disassembling the unit, replacing the shaft seal, etc.).

Table 2 showed the results obtained through the REBA method, where positions of the limbs have been analysed of Group A (trunk, neck, and legs), and Group B (arm, lower arm, wrist). In Group A, the trunk score was 3.98, higher than that obtained for the neck, with 2.86 , followed by the legs with 1.72 , which showed that positions performed with the trunk represented a high level of musculoskeletal risk. On the other hand, the data obtained from Group B showed that the highest average of all the positions used in this group was the arm, which represented 4.21, two points above the lower arm and 2.28 points above the wrist.

Table 2. Descriptive statistics of the results obtained using the REBA method.

\begin{tabular}{cccc}
\hline \multicolumn{2}{c}{ REBA Method Scores } & Average & SD \\
\hline \multirow{2}{*}{ Group A } & Trunk & 3.98 & 0.913 \\
& Neck & 2.86 & 0.351 \\
& Legs & 1.72 & 0.854 \\
\hline \multirow{2}{*}{ Group B } & Arm & 4.21 & 0.675 \\
& Lower Arm & 2.21 & 0.412 \\
\hline Final & Wrist & 1.93 & 0.737 \\
\hline
\end{tabular}

Note: Group A (trunk, neck, and legs), and Group B (arm, lower arm, wrist).

There was greater musculoskeletal risk in positions performed with the arm. The average overall score of the data obtained using the REBA method in our assessment was 10.49 with a standard deviation (SD) of 1.33. This signified the existence of a Level 3, which implied high risk to suffer from musculoskeletal disorders and the necessity to take action as soon as possible (Table 3).

Table 3. Classification of risk level based on the REBA method [13].

\begin{tabular}{ccc}
\hline Score & Risk Level & Need for Action \\
\hline 1 & Negligible & None necessary \\
2 or 3 & Low & May be necessary \\
4 to 7 & Medium & Medium necessary \\
8 to 10 & High & Necessary soon \\
11 to 15 & Very high & Necessary now \\
\hline
\end{tabular}

Note. Reprinted from Hignett, S.; McAtamney, L. Rapid Entire Body Assessment (REBA). Appl. Ergon. 2000, 31 201-205. https:/ / doi.org/10.1016/S0003-6870(99)00039-3. Copyright (2000), with permission from Elsevier. 
There were significant differences between the tasks performed $\left(\mathrm{H}=9.728 ; p=0.045^{*}\right)$, the transmission assembly and disassembly task had a higher average REBA score $(11.5 \pm 1.38)$, which required immediate action.

With regard to sociodemographic variables, no association was found between the REBA method scores and age, work experience, height, BMI, workplace, and professional category $(p>0.05)$.

It has also been assessed whether the mechanics used orthopaedic support to do the tasks, such as back braces and lumbar belts, elastic back supports, and/or posture shirts. The orthopaedic support most used by workers according to their questionnaire responses was the lumbar brace. The association between the use of orthopaedic support and the scores of different body parts assessed by the REBA Method has been analysed. The results showed there was a significant difference in the trunk score when orthopaedic support was used or not used $\left(Z=-2.375 ; p=0.018^{*}\right)$. For workers who did not use orthopaedic support, the average trunk score was higher $(4.15 \pm 0.87)$ than when it was used $(3.4 \pm 0.84)$.

Another point assessed was whether the mechanics had some type of hobby or perform activities that required physical effort other than their work at the company. The averages of the final REBA method score were $11 \pm 1.106$ and $10.08 \pm 1.381$, respectively. That is, the workers who performed other activities requiring physical effort outside their workday usually used postures with higher musculoskeletal risk $\left(Z=-2.391 ; p=0.017^{*}\right)$.

\subsection{The Effect of Training and Postural Feedback}

Finally, regarding comparison with the experimental group: results before and after the training/feedback (Table 4 ), the results showed a significant reduction in overall musculoskeletal risk $\left(Z=-2.26 ; p=0.026^{*}\right)$, and in Group A (neck, trunk, and legs) $\left(Z=-2.21 ; p=0.027^{*}\right)$. Nevertheless, no significant results were found in Group B (arm, lower arm, and wrists).

Table 4. Comparison of results before and after training/feedback in the experimental group.

\begin{tabular}{cccccc}
\hline REBA Assessment & Average & Re-Assessment & Average & $\mathbf{Z}^{+}$ & $p$-Value \\
\hline Group A & 7.17 & Group A & 4 & -2.214 & $0.027^{*}$ \\
Group B & 5.33 & Group B & 6 & -1.342 & 0.18 \\
Overall & 10 & Overall & 7 & -2.226 & $0.026^{*}$ \\
\hline
\end{tabular}

Note. ${ }^{+}$Wilcoxon Signed Ranks Test. ${ }^{*} p<0.05$.

\section{Discussion}

The average REBA score in the group of mechanics assessed was 10.49, indicating a high level of risk and warning of the need for upcoming intervention to eliminate and/or reduce it. Several research projects agree in this regard $[19,20]$, as they consider that the overexertion produced by manual handling of loads is the main cause of the appearance of musculoskeletal disorders affecting all aspects of the worker's daily and work life.

Scores measured using the REBA method showed a small difference between Group A (trunk, neck, and legs) and Group B (arm, lower arm, and wrist). Among the body segments analysed, higher levels were seen in the arms (4.21) and trunk (3.98), showing that these parts of the body were obviously more affected by musculoskeletal injuries. This result is consistent with many earlier studies [21-23].

The task identified as the most harmful is assembly and disassembly of the transmission $(p=0.045)$, with an average score of 11.5 , results that are similar to those found in research carried out by the Department of Labour Health of the CCOO (workers' union) in Madrid [24], which notes that the main risks for musculoskeletal illness in service garages originates in load handling tasks and mainly in the assembly and disassembly of heavy parts.

Comparing the analytical results of the REBA with other variables that have been taken into consideration, we identified significant differences in the variable related to orthopaedic supports (providing stability and anchoring for the back), reducing the score 
to 3.4 for workers who used these while carrying out their tasks, compared to a score of 4.15 in the case of not using orthopaedic support for the trunk. However, these data should be regarded with caution, as it may be affecting an assessment positively but creating more problems in the long run without reducing pain, as noted in the report from the National Institute for Occupational Safety and Health (NIOSH) [25], whose study of 9377 employees "found no evidence that back belts reduce injuries or back pain for retail workers who lift or move merchandise".

Another significant piece of information from these variables was that workers who had a hobby or do activities that required physical effort after their work day used postures with higher musculoskeletal risk. Some studies show that physical exercises can improve the body's flexibility and stability [26,27] and make it more difficult for them to realize the harm forced postures are doing to their body. In this regard, training on ergonomics and correct work postures is important.

It worth noting that actions taken for postural training and feedback are helping workers reduce postural risk and thus to reduce associated musculoskeletal disorders. Just as pointed out in research that has been developed $[28,29]$. This can be a line of action, as it does not require high costs and can help to significantly reduce risk.

Finally, we considered the limitations of the research, and they will be resolved in future research. On the one hand, the sample size of the study is small. We invited all truck and bus mechanics from the eight workplaces of SCANIA company to participate. However, as the first experiment, $21 \%$ of them voluntarily participated. Although in this study training and postural feedback have been proven in reduction of musculoskeletal risk, future studies should expand the sample size. On the other hand, since the research was conducted in various workplaces in various cities, data collection was carried out in a short period of time. Therefore, it is recommended to continue to follow up these subjects in future studies and complete the longitudinal study.

\section{Conclusions}

The assessment using the REBA method, for the posture used by mechanics of arms raised above the shoulders, has resulted in an average score of 10.49. This indicates, according to factors from the method, a high level of risk and is a warning to intervene urgently to eliminate and/or reduce this.

The REBA method has been useful since it allows distinguishing between Group A (trunk, neck, and legs) and Group B (arm, lower arm, and wrist). The results show increased risk in the trunk within Group A and in the arms for Group B.

Analysis of the work shows the impossibility of completely eliminating risk; it is not possible to prevent the mechanics from carrying out the assessed tasks using a different posture. What can indeed be considered are preventive measures and improvements in work tools that can reduce musculoskeletal risks.

The training and postural feedback provided to the mechanics have been positively assessed as preventive measures, with improvement seen in data obtained when the same task was reassessed. In addition, it is an easy and economical solution that helps motivate the worker. Nevertheless, it is necessary to assess, with larger samples, their effectiveness and the stability of the scores some months after their implementation.

\section{Future Recommendations}

In the information collected in this research, the possibility for improvement is considered for a number of issues that need to be taken into account, such as to:

- Adjust the height of the lifts prior to working and during the course of the repair, to avoid an arched back posture and so they can work with their back straight, reducing pressure on the lumbar and cervical areas.

- Have a mobile side table on which to place tools and parts to be used while doing the task. This is so the worker can reach them without having to continuously go in and out below the lift, reducing the $>60^{\circ}$ bending of the trunk produced by this movement. 
- Assess the possibility of the company purchasing tool trolleys with low drawers that can be accessed below the lifts.

- Use a tie strap to support the transmission and thus prevent its lowering and the unnecessary manual handling of loads.

- Facilitate the creation of a tool to help them reduce manual handling of loads in transmission assembly/disassembly work, as this is a part that weighs $60 \mathrm{~kg}$. This tool will allow the transmission part to be lowered without the need for the worker to intervene by handling loads.

- Intervene in the upper-limb exoskeleton, which has been tested by workers. They have provided fairly positive comments and assessments, reporting a feeling of lightness, assistance, and relief at all times (Figure 2). It remains pending to do an in-depth and more objective analysis using the EMG instrument in order to assess the benefits it could specifically contribute to reducing musculoskeletal risks.

Due to time constraints, we have not been able to quantitatively assess all of these measures in this study. Therefore, it is recommended to continue monitoring the participants, or that a longitudinal study be designed in future research in order to assess the effectiveness of these improvement measures in reducing musculoskeletal risks in the medium to long term.

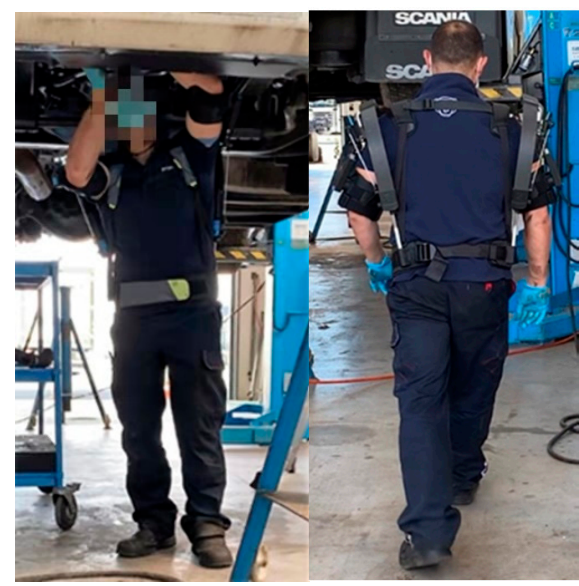

Figure 2. Worker with upper-limb exoskeleton.

Author Contributions: Conceptualization, C.O.H. and I.M.R.; methodology, S.L.; software, S.L.; validation, M.J.A.B., I.M.R. and C.O.H.; formal analysis, S.L.; investigation, S.L.; data curation, C.O.H.; writing-original draft preparation, S.L., C.O.H. and I.M.R.; writing-review and editing, M.J.A.B.; visualization, M.J.A.B.; supervision, C.O.H., M.J.A.B. and I.M.R.; project administration, I.M.R. All authors have read and agreed to the published version of the manuscript.

Funding: This research received no external funding.

Institutional Review Board Statement: The study was conducted according to the guidelines of the Declaration of Helsinki, and approved by the Andalusian Research Ethics Committee (REC of the Virgen Macarena-Virgen del Rocio university hospitals: d9b449426c41062448a2d8be713a0b063741ae96).

Informed Consent Statement: Informed consent was obtained from all subjects involved in the study.

Data Availability Statement: The study did not report any data.

Acknowledgments: This study was not easy to complete during the COVID-19 pandemic. There are many people who have contributed to this research, and we would like to express our gratitude to them. We sincerely thank all participants for their cooperation in the research. We are grateful to Velasco, S.; Piras, G.; Ramos, and Marchante, A., for their help in data collection and video recording. We thank Iturri, S.A. for providing us with the upper-limb exoskeleton, and also thank Vicente, L. and González, L. for testing them. Finally, we would like to thank the administrative team of SCANIA and Complutense University of Madrid for their full support of this work. They have collaborated in the investigation: Velasco, S. \& Marchante, A. 
Conflicts of Interest: The authors declare no conflict of interest.

Appendix A. Sociodemographic Questionnaire (Please View the English Version below the Original Questionnaire)

\section{CUESTIONARIO SCANIA}

Datos sociodemográficos

Sexo $\quad \square \mathrm{H} \quad \square \mathrm{M}$

Edad:

Altura:

Peso:

Puesto de trabajo:

Categoría profesional:

Centro de trabajo:

1. ¿Cuántos años lleva trabajado en esta profesión?

2. ¿Cuántos años lleva trabajado en esta SCANIA?

3. ¿Qué reparaciones son las que haces con más frecuencia?

4. ¿Cuánto tiempo dedicas de tu jornada a la manipulación manual de cargas?

$\square$ Nunca

$\square$ De 0 a $2 h$

$\square$ De $2 \mathrm{~h}$ a $4 \mathrm{~h}$

$\square$ Mas de $4 \mathrm{~h}$

5. ¿Cuánto tiempo de tu jornada dedicas a posturas forzadas?

Brazos por encima de los hombros, en cuclillas etc.

Nunca

$\square$ De 0 a $2 h$

De $2 h$ a $4 h$

Mas de $4 h$

6. ¿Cúal es la(s) postura(s) que te cuentan mas o consideras que te perjudican?

7. ¿utilizas equipos o maquinarias que te facilitan manipular cargas? $\mathrm{SI}$ NO $\square$

Figure A1. Sociodemographic questionnaire designed for this study (page 1). 


\section{CUESTIONARIO SCANIA}

8. ¿Realizas o tienes algún hobbie/ actividad que te requiera esfuerzo físico, aparte de tu trabajo en SCANIA?

$\square \mathrm{SI}$

$\square$ No, (sí, marcas esta opción pasar a la pregunta 10)

9. ¿Cuánto tiempo dedicas a realizar este otro hobbie/ actividad?

10. ¿Utilizas alguna ayuda ortopédica para proporcionar estabilidad y fijación en la parte inferior de la espalda?

$\square \mathrm{SI}$

$\square$ No, (sí, marcas esta opción pasar a la pregunta 11)

10. 1. Marque cual de estos dispositivos utilizas

Faja lumbar

$\square$ Cinturón lumbar

$\square$ Espaldilleras

$\square$ Camisetas posturales

$\square$ Otros:

10. 2 ¿En qué tipo de reparaciones lo utilizas?

10. 3. ¿Con qué frecuencia diaria?

$\square$ Nunca

$\square$ Para trabajo puntual

$\square$ En la mayor parte de los trabajos

$\square$ Siempre

11. ¿Las tareas que normalmente realizas requieren la ayuda de otro compañero de trabajo?
Sí, Siempre
$\square$ Algunas veces
Nunca

12. ¿Sientes que hay compenetración/ compañerismo en é equipo?

$$
\text { SI } \square \text { No } \square
$$

13. ¿Has recibido alguna formación sobre manipulación manual de carga?

$$
\text { SI } \square \quad \text { NO } \square
$$

14. ¿Has recibido alguna formación sobre higiene posturas?

SI $\square \quad$ NO $\square$

Figure A2. Sociodemographic questionnaire designed for this study (page 2).

(Translate) SCANIA Questionnaire

Sociodemographic information

Sex: M F

Age:

Height:

Weight:

Job position: 
Professional category:

Workplace location:

1. How long have you been working in this profession?

2. How long have you been working at this SCANIA?

3. What are the repairs you do most often?

4. How much of your day do you spend doing manual handling of loads?

None

From 0 to $2 \mathrm{~h}$

From 2 to $4 \mathrm{~h}$

More than $4 \mathrm{~h}$

5. How much of your day do you spend in forced postures? Arms above your shoulders, squatting, etc.

None

From 0 to $2 \mathrm{~h}$

From 2 to $4 \mathrm{~h}$

More than $4 \mathrm{~h}$

6. What is the posture(s) that is most difficult for you or you feel is most harmful?

7. Do you use equipment or machinery that helps you handle loads?

Yes No

8. Do you have any hobby/activity that requires physical effort, apart from your work at SCANIA?

Yes

No (if you choose this option, move on to question 10)

9. How much time do you devote to this other hobby/activity?

10. Do you use any type of orthopedic assistance to provide stability and support for the lower back?

Yes

No (if you choose this option, move on to question 11)

10.1 Mark which of these devices you use

Back brace

Lumbar belt

Elastic back supports

Posture shirts

10.2 In which types of repairs do you use this?

10.3 With what daily frequency?

Never

For occasional jobs

In most of the jobs

Always

11. Do the tasks you usually do require the help of a workmate?

Yes, always

Sometimes

Never

12. Do you feel there is rapport/camaraderie on the team?

Yes No

13. Have you received any training on manual handling of loads?

Yes No

14. Have you received any training on postural hygiene?

Yes No 
Appendix B. The Signed Informed Consent form of the Participants Involved in the Pictures in This Article

Yo, L I el propósito y características del proyecto de Nuevos retos en la intervención del riesgo musculoesquelético en talleres de camiones para el que se solicita mi colaboración.

ACEPTO la inclusión en dicho estudio y manifiesto que los datos POR Mí APORTADOS son ciertos. Así mismo permito la utilización de la información suministrada e imágenes tomadas con fines docentes e investigadores.

Por todo ello, OTORGO MI CONSENTIMIENTO de forma libre y voluntaria a mi participación una vez leída y comprendida la hoja de información sobre el estudio otorgando mi autorización al tratamiento de mis datos e imágenes con fines investigadores y docentes por el equipo investigador que podrá ser publicado en revista científica.

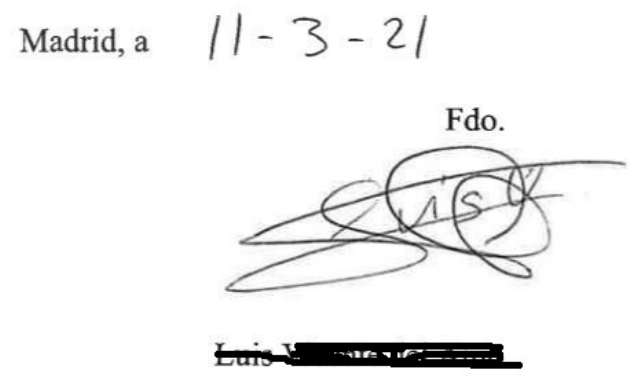

Figure A3. Informed consent form signed by one of the participants involved in the picture in the article. 
Yo, manifiesto que he sido informado sobre el propósito y características del proyecto de Nuevos retos en la intervención del riesgo musculoesquelético en talleres de camiones para el que se solicita mi colaboración.

ACEPTO la inclusión en dicho estudio y manifiesto que los datos POR Mí APORTADOS son ciertos. Así mismo permito la utilización de la información suministrada e imágenes tomadas con fines docentes e investigadores.

Por todo ello, OTORGO MI CONSENTIMIENTO de forma libre y voluntaria a mi participación una vez leída y comprendida la hoja de información sobre el estudio otorgando mi autorización al tratamiento de mis datos e imágenes con fines investigadores y docentes por el equipo investigador que podrá ser publicado en revista cientifica.

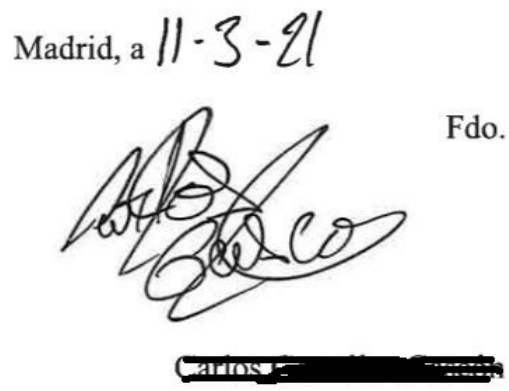

Figure A4. Informed consent form signed by another participant involved in the picture in the article.

\section{References}

1. Subdirección General de Estadísticas y Análisis Sociolaboral. Estadística de Accidentes de Trabajo (ATR); Subdirección General de Estadísticas y Análisis Sociolaboral: Madrid, Spain, 2020.

2. Health and Safety Executive. Work Related Musculoskeletal Disorder Statistics (WRMSDs) in Great Britain, 2020; Health and Safety Executive: Bootle, UK, 2020.

3. EU-OSHA. Trastornos Musculoesqueléticos. In European Agency for Safety and Health at Work; EU-OSHA: Bilbao, Spain, 2021.

4. Keyserling, W. Factores de Riesgo En El Lugar de Trabajo y Trastornos Musculoesqueléticos Ocupacionales, Parte 1: Una Revisión de La Investigación Biomecánica y Psicofísica Sobre Los Factores de Riesgo Asociados Con El Dolor Lumbar. Am. Ind. Hyg. Assoc. J. 2000, 61, 39-50. [CrossRef]

5. Lyons, J. Factores Que Contribuyen al Dolor Lumbar Entre Los Conductores Profesionales: Una Revisión de La Literatura Actual y Los Posibles Controles Ergonómicos. Work 2002, 19, 95-102. [PubMed]

6. Szeto, G.P.Y.; Lam, P. Trastornos Musculoesqueléticos Relacionados Con El Trabajo En Conductores de Autobuses Urbanos de Hong Kong. J. Occup. Rehabil. 2007, 17, 98-181.

7. Galinsky, T.; Waters, T.; Malit, B. Lesiones Por Sobreesfuerzo En Los Trabajadores de La Salud Domiciliaria y La Necesidad de Ergonomía. Home Health Care Serv. Q. 2001, 20, 57-73. [CrossRef]

8. Fonseca, N.D.R.; Fernandes, R.D.C.P. Factores Asociados a Los Disturbios Músculo-Esqueléticos En Enfermería. Rev. Lat. Am. De Enferm. 2010, 18, 1076-1083. [CrossRef] [PubMed]

9. Cebrián Angulo, J.L.; Rosario, P.A. Formación de Seguridad Laboral; Ediciones Paraninfo, S.A.: Madrid, Spain, 2019 ; pp. 11-14.

10. Syed Mohamed, M.S.; Basiri, M.N.H. Working Posture Assessment in a Small and Medium Industry (SMI): Automotive Repair Facility. Appl. Mech. Mater. 2015, 761, 664-667. [CrossRef]

11. Tamene, A.; Mulugeta, H.; Ashenafi, T.; Thygerson, S.M. Musculoskeletal Disorders and Associated Factors among Vehicle Repair Workers in Hawassa City, Southern Ethiopia. J. Environ. Public Health 2020, 2020, 9472357. [CrossRef]

12. Anyaeche, C.O.; Ishie, P. Ergonomic Assessment of Risk Factors for Musculoskeletal Disorder in Selected Auto Repair Shops. J. Appl. Sci. Eng. Technol. 2021, 16, 19-27.

13. Hignett, S.; McAtamney, L. Rapid Entire Body Assessment (REBA). Appl. Ergon. 2000, 31, 201-205. [CrossRef]

14. Schwartz, A.H.; Albin, T.J.; Gerberich, S.G. Intra-Rater and Inter-Rater Reliability of the Rapid Entire Body Assessment (REBA) Tool. Int. J. Ind. Ergon. 2019, 71, 111-116. [CrossRef] 
15. Yoon, S.-Y.; Ko, J.; Jung, M.-C. A Model for Developing Job Rotation Schedules That Eliminate Sequential High Workloads and Minimize Between-Worker Variability in Cumulative Daily Workloads: Application to Automotive Assembly Lines. Appl. Ergon. 2016, 55, 8-15. [CrossRef] [PubMed]

16. Sandeep, K.G.; Jayan, J.T. Ergonomic Assessment in Vehicle Assembly Line Using REBA Tool. Int. Res. J. Eng. Technol. 2020, 7, 1363-1368.

17. Moradi, M.; Poursadeghiyan, M.; Khammar, A.; Hami, M.; Darsnj, A.; Yarmohammadi, H. REBA Method for the Ergonomic Risk Assessment of Auto Mechanics Postural Stress Caused by Working Conditions in Kermanshah (Iran). Ann. Trop. Med. Public Health 2017, 10, 589-594. [CrossRef]

18. Weir, C.B.; Jan, A. BMI Classification Percentile and Cut Off Points; StatPearls Publishing: Treasure Island, FL, USA, 2019.

19. Morales Perrazo, L.; Ramón Díaz, M.; Collantes Vaca, S.; Aldás Salazar, D. Riesgo Ergonómico Por Levantamiento de Cargas. Caso de Estudio “Talleres de Mantenimiento Vehicular de Maquinaria Pesada”. Rev. Científica Y Tecnológica UPSE 2019, 6, 17-26. [CrossRef]

20. Castro-Castro, G.C.; Ardila-Pereira, L.C.; Orozco-Muñoz, Y.D.S.; Sepulveda-Lazaro, E.E.; Molina-Castro, C.E. Factores de Riesgo Asociados a Desordenes Musculo Esqueléticos En Una Empresa de Fabricación de Refrigeradores. Rev. De Salud Publica 2018, 20, 182-188. [CrossRef]

21. Torp, S.; Riise, T.; Moen, B.E. Work-Related Musculoskeletal Symptoms among Car Mechanics: A Descriptive Study. Occup. Med. 1996, 46, 407-413. [CrossRef]

22. Nasaruddin, F.A.; Md Tamrin, S.; Karuppiah, K. The Prevalence of Musculoskeletal Disorder and the Association with Risk Factors among Auto Repair Mechanics in Klang Valley, Malaysia. Iran. J. Public Health 2014, 43, 34-41.

23. Aziz, F.A.; Ghazalli, Z.; Mohamed, N.M.Z.; Isfar, A. Investigation on Musculoskeletal Discomfort and Ergonomics Risk Factors among Production Team Members at an Automotive Component Assembly Plant. In IOP Conference Series: Materials Science and Engineering; IOP Publishing: Bristol, UK, 2017; Volume 257, p. 012040. [CrossRef]

24. Instituto Regional de Seguridad y Salud en el. Trabajo Métodos de Evaluación Ergonómica; Comisiones Obreras de Madrid: Madrid, Spain, 2016; pp. 1-70.

25. Blosser, F. CDC-NIOSH Update-No Evidence That Back Belts Reduce Injury Seen in Landmark Study of Retail Users; Instituto Nacional para la Seguridad y Salud Ocupacional: Washington, DC, USA, 2014; pp. 8-10.

26. Mailloux, J.; Finno, M.; Rainville, J. Long-Term Exercise Adherence in the Elderly with Chronic Low Back Pain. Am. J. Phys. Med. Rehabil. 2006, 85, 120-126. [CrossRef] [PubMed]

27. Segal, N.A.; Hein, J.; Basford, J.R. The Effects of Pilates Training on Flexibility and Body Composition: An Observational Study. Arch. Phys. Med. Rehabil. 2004, 85, 1977-1981. [CrossRef]

28. Hoe, V.C.W.; Urquhart, D.M.; Kelsall, H.L.; Sim, M.R. Ergonomic Design and Training for Preventing Work-Related Musculoskeletal Disorders of the Upper Limb and Neck in Adults. Cochrane Database Syst. Rev. 2012, 2017, CD008570. [CrossRef]

29. Zare, M.; Black, N.; Sagot, J.C.; Hunault, G.; Roquelaure, Y. Ergonomics Interventions to Reduce Musculoskeletal Risk Factors in a Truck Manufacturing Plant. Int. J. Ind. Ergon. 2020, 75, 102896. [CrossRef] 